DOI 10.4467/2543733XSSB.21.014.13807

\author{
KATERINA TODOROSKA \\ Institute of National History \\ Skopje
}

\title{
MACEDONIAN DOMESTIC AND INTERNATIONAL PROBLEMS (1990-2019)
}

\begin{abstract}
Summary
The article addresses the complex relations between the Republic of Macedonia and the neighboring countries formed after the breakup of Yugoslavia in 1991. Several reasons behind said difficulties are discussed, namely: the dispute between Serbia and Macedonia concerning Belgrade's lack of recognition of the Autocephaly of the Macedonian Orthodox church, the conflict with Albanians, who point out to human rights violations by the government in Skopje, and the contestations between North Macedonia and Bulgaria addressing Bulgaria's suppression of Macedonian national identity and language in the province of Pirin Macedonia (Blagoevgrad Province). Finally, we discuss the conflict with Greece concerning the name of the Macedonian state and the rights of Macedonian immigrants.
\end{abstract}

Keywords: Republic of Macedonia, Macedonian independence, neighbors of Macedonia

The breakdown of the SFR Yugoslavia and the independence of Macedonia brought the state and the Macedonian people to a period of transitional changes. Namely, the Socialist Republic of Macedonia, for the needs of the new time, declared independence at the referendum of September 8, 1991. The Macedonian citizens were asked to answer the following question: "Do you agree to a sovereign or an independent State of Macedonia, with the right to join a future union of sovereign states of Yugoslavia"?

$75.75 \%$ of the citizens with the right to vote went to the polls, and $95.1 \%$ of the voters voted "FOR". Thus, an independent sovereign Republic of Macedonia was created".

${ }^{1}$ The Republic of Macedonia is in the central part of the Balkan Peninsula, with a total area of $25,713 \mathrm{~km}^{2}$, or $38.6 \%$ of the geographical space that bears the name Macedonia in the Balkans. See in: Македонија и соседите. 15 години независност. Приредувачи: Методија Манојловски, Катерина Тодороска, Јордан Поп-Атанасов, Том 3, Скопје 2010, 10. 
With that, the Republic of Macedonia emerged as a new entity in international relations. Its appearance and existence changed the geopolitical relations in the Balkans until then and became a new element in the distribution of forces in the region.

From the moment of its independence, the Republic of Macedonia faced numerous temptations, both internally (within the existing until then federal state) and internationally, on the way to achieving its international establishment.

Wanting to annul the neighbors' efforts to portray the new state as a factor of instability in the Balkans and an aspirant to parts inhabited with the Macedonian minority in the neighboring countries ${ }^{2}$, on January 6, 1992, "The Assembly of the Republic of Macedonia adopted a decision declaring two amendments to the Constitution of the Republic of Macedonia, which are related to Article 3 and Article 4 of the Constitution of the Republic of Macedonia, emphasizing that the Republic of Macedonia has no territorial pretensions to neighboring countries. The border of the Republic of Macedonia can be changed only in accordance with the Constitution and that the Republic will not interfere in the sovereign rights of other states..."”.

The transition for Macedonians meant the transition from a peaceful and calm everyday life, followed by secure jobs and wages, to a temperamental life marked by a daily struggle for survival and earnings. What was and remains the biggest flaw of the transition in Macedonia is that all the started processes have remained somewhere in the middle. The process of denationalization of the properties of the Macedonian citizens was started, which was neither implemented according to the adopted Law on Denationalization, nor completed; then the process of privatization of the social enterprises began with a lot of noise and resulted in an army of fired workers who did not know how to cope with the new created conditions. And so, everything began with the healing of some wounds, which were left untreated completely, and new ones were being opened that were even bigger and more painful.

Internationally, the Macedonian state had numerous obstacles, due to which on April 9, 1993, it was admitted as the $181^{\text {st }}$ member to the United Nations as the former Yugoslav Republic of Macedonia, and not under its constitutional name ${ }^{4}$.

Bulgaria was the first country that recognized the independence of the Republic of Macedonia on January 15, 1992, but did not recognize the existence of the Macedonian people and the Macedonian language. In such a way, Bulgaria continued its long-standing policy of denying Macedonian history and culture.

On April 8, 1996, the Republic of Macedonia was also recognized by the Federal Republic of Yugoslavia, when diplomatic relations were established between the two countries. Macedonia's northern neighbor has not officially recognized the Macedonian Orthodox Church's autocephaly. With that, the position of the Serbian Orthodox Church

\footnotetext{
${ }^{2}$ After the end of the Balkan Wars (1912/13), the division of Macedonia was formalized with the Bucharest Agreement of August 10, 1913. World War I did not bring anything new to the status of the Macedonian territory, because only with minor territorial adjustments, at the expense of Bulgaria in favor of Serbia, the Paris Peace Conference (1919) sanctioned the provisions of the Bucharest Agreement. Thus, officially the largest part of Macedonia $35,169 \mathrm{~km}^{2}$ fell to Greece, $25,713 \mathrm{~km}^{2}$ to the Kingdom of SHS and $6,798 \mathrm{~km}^{2}$ to Bulgaria. See in: Македонија и соседите. 15 години независност..., 10.

${ }^{3}$ Спасе Мирчески, Алманах на Република Македонија (хронологија 1990-1997), Скопје 1998, 37.

${ }^{4}$ Zeqirija Rexhepi, Socio-political Events of Albanians in Macedonia 1991-2001, Tetovo 2007, 7.
} 
which considered that the Macedonian Orthodox Church should be only a part of it, was renewed.

On April 26, 1993, the Republic of Albania recognized the independence of our country, but under the reference of the former Yugoslav Republic of Macedonia.

In the next period, the Macedonian state signed numerous bilateral agreements with neighboring countries in the field of economic, cultural, educational cooperation.

In those sensitive years, the Macedonian state had major internal turbulences, which were primarily caused by some radical persons who appeared on the political scene.

Thus, in Macedonia, the Albanian population had the right to have their complete education in their native Albanian language at all levels of education. As for the political engagement of the Albanian population in the R. of Macedonia, the People's Democratic Party led by President Iljaz Halimi was registered in January $1990^{5}$. Then, numerous parties of Albanians in Macedonia were registered with a purely ethnic nature ${ }^{6}$, while several of them were with a public focus on the destruction of the Macedonian state. The Albanian population in the R. of Macedonia can be culturally elevated by attending theatrical and other cultural events in the premises of the Albanian Drama at the Theater of Nationalities in Skopje. Despite such facts, on January 10 and 11, 1992, the Albanians in the R. of Macedonia held a so called referendum on political and territorial autonomy ${ }^{7}$, while in Struga, on April 3, 1992, the branch of the Party for Democratic Prosperity organized a protest rally at which, among others, the formation of the so-called autonomous republic "Ilirida", was announced.

In early 2001, the Macedonian state faced another domestic problem in relation to the Albanian population, when an armed conflict began between the National Liberation Army (NLA) and the Macedonian army and police. The reason for the armed conflict was that the Albanians in Macedonia claimed to have not enjoyed basic human rights, which was far from the truth. However, the military action aroused great interest among the international community, and thus gained international character. The armed conflict, like all other wars, was resolved on August 13, 2001 by signing the so-called "Framework Agreement" in Skopje, and signed in the presence of "European facilitators". Then, for the need of "European peace" installed in Macedonia, this agreement was extended in the desired direction and required length. The years to follow were devoted to the implementation of the Framework Agreement in Macedonia to improve and calm the coexistence between the Macedonian and Albanian populations, and bilateral relations between Macedonia and Albania were legalized for a number of questions related to the bilateral issues.

Unlike the rights of the Albanian population in Macedonia, Macedonians in Albania have been treated as Albanians, they did not have the right to express their ethnicity even during the 2000 census, when Albania had already entered the period of transition and democratization of the society. Such behavior of an official state towards a minority was

\footnotetext{
${ }^{5}$ Спасе Мирчески, Алманах на Република Македонија..., 11.

${ }^{6}$ On April 15, 1990, the Party for Democratic Prosperity was founded in Tetovo, and Nevzat Halili was elected the first president. On August 1, 1991. The Party for Democratic Action - Islamic Road in Tetovo was registered, and Kenan Mazlimi was appointed the first president. Спасе Мирчески, Алманах на Република Македонија..., 13-29.

${ }^{7}$ Спасе Мирчески, Алманах на Република Македонија..., 37.

${ }^{8}$ Спасе Мирчески, Алманах на Република Македонија..., 40.
} 
unclear, because the Macedonians concentrated in Mala Prespa have the right to study primary education in Macedonian language. In Mala Prespa, Macedonian children learn the Macedonian language, as a native language two hours per week also in the first two years of secondary education ${ }^{9}$. With the formation of the only Macedonian party, the need of the Macedonian population for independent participation in the legal parliamentary elections in the Republic of Albania was supposed to have been met. It is illusory to speak about cultural institutions that would nurture and practice the culture of the Macedonian language. Unfortunately, public gatherings in support of the Macedonians in neighboring countries will take place only from time to time ${ }^{10}$, the dissatisfaction with the treatment of Macedonians will be publicly expressed in front of the international institutions ${ }^{11}$, or some institution or labor organization or NGO from the Republic of Macedonia will dare to visit Macedonians in Albania and to donate textbooks and other literature in Macedonian language.

In the Bulgarian state, there is a traditional opinion about the Bulgarian character of the Macedonian people and language, and today opinions on this issue are divided among the Bulgarian population. Among the younger generations, there are currents when it comes to Macedonian national sovereignty. In a word, there are differences. They range from accepting the reality, that is, the existence of the Macedonian national sovereignty, language, history, culture in the Republic of Macedonia, to the complete denial of that reality. Therefore, the Bulgarian scientifics, politically motivated, remains on the firm stand on the Bulgarian roots of the Macedonian people and state. The same applies to the highest representatives of the Bulgarian state and political life. Starting from the time of Todor Zhivkov onwards, regardless of the ideological and political differences, when it comes to the relationship with the Macedonian national sovereignty, there is complete unity ${ }^{12}$.

Searching for modern reasons for such a firm attitude to Bulgarian politics and journalism, a very pragmatic answer arises. That is the fear for the future of the Pirin part of Macedonia. Fear of the survival, development and consolidation of the national consciousness in that part of Macedonia.

Despite the brutality that the Macedonians faced with in Bulgaria, in the years following the 1948 IB Resolution until the end of 1980s, due to its "excesses" to seek national rights, however, the Macedonian national minority in Pirin Macedonia, have had a stronger need of its own promotion and, finally the acquisition of basic human rights in the country in which they lived. Such an urge was the reason for the establishment of the Independent Association - Macedonian organization "Ilinden (VMRO - independent)" on November 14, 1989 in Sofia. Immediately afterwards, the anti-Macedonian sentiments in Bulgaria flared up, and as a result, on November 27, 1989 a rally was held demanding unification of the whole of Macedonia to Bulgaria and uniting of the Bulgarian brothers

\footnotetext{
${ }^{9}$ In Albania, Macedonians were engaged in four associations, while the political party was registered, after fifteen years of democracy in Albania, in 2005. More for this theme in Катерина Тодороска, Македониите во Албанија (1912-1991), Скопје 2016, 32.

${ }^{10}$ Спасе Мирчески, Алманах на Република Македонија..., 12.

${ }^{11}$ On June 22, 1990, in Copenhagen, at the Conference on the Human Dimension of the CSCE, the Yugoslav delegation submitted a Memorandum on the position of the Macedonian national minority in Bulgaria, Greece and Albania. Спасе Мирчески, Алманах на Република Македонија..., 14.

${ }^{12}$ Ivan Katardjiev, Macedonia and its Neighbors, Skopje 2001, 31-40.
} 
from Macedonia and Serbia with Mother Bulgaria. The Great Bulgarian positions were especially emphasized on November 27, 1989 by establishment of the Association of Macedonian Cultural and Educational Societies in Bulgaria, whose president was Dimitar Gocev. This Association, on February 22, 1990 divulged the renewal of the newspaper "Macedonia", which according to the announcements should have dealt with the problems of Bulgarians in the diaspora and in Macedonia, in order for them to learn the truth about their historical and cultural roots ${ }^{13}$. In response to the aggressive anti-Macedonian policy in Bulgaria, numerous associations of the Macedonian population began to be established, and on April 14, 1990, in Sandanski. a unifying meeting was held of representatives of "Ilinden VMRO-independent" from Blagoevgrad, KPD "Jane Sandanski” from the village Mikrevo, the Committee of Repressed Macedonians from Bulgaria, the Committee for Protection of Macedonian Rights in Bulgaria and the "Independent Democratic Union" from Blagoevgrad, Simitli, Krupnik, Bansko and others. The epilogue of the meeting was the creation of the United Organization OMO "Ilinden"". It was also joined by the "VMRO Ilinden" independent association from Sofia. After preparing the necessary documentation, on May 14, 1990 the request for registration of OMO "Ilinden" was submitted to the District Court in Blagoevgrad. Attached to the request were the Statute and the Program of the Organization, in which the organizers referred to the applicable regulations in Bulgaria and the UN Universal Declaration of Human Rights. Although OMO Ilinden activists believed in the seriousness of Bulgaria's signature on the UN Declaration, they still took a cold shower the same day as the National Constitution Protection Service accused the organization of opposing Bulgaria's territorial integrity and the unity of the nation. Based on the submitted documentation, the National Service came to the conclusion that "OMO's activity is unconstitutional, separatist and anti-Bulgarian, in order to 'establish a new independent Macedonian state within the ethnic borders of Pirin, Aegean and Vardar Macedonia', which means secession of Pirin Macedonia from Bulgaria"15. Attacks on OMO Ilinden members and activists have been intensified. Based on the tension created, on June 6, 1990 the district court in Blagoevgrad, at a session held behind closed doors, rejected the request of OMO "Ilinden" for its registration according to Bulgarian legal norms ${ }^{16}$. Irritated by this decision, the activists of the Organization declared the so-called "Relay strike" with hunger. However, their actions was severely punished by the police, and the strikers were even asked to cooperate with the Bulgarian state security services. This attitude of the state authorities towards the Macedonian minority in Bulgaria provoked the members and supporters of OMO "Ilinden" to declare a boycott of the first multi-party elections held in Bulgaria on June 10, 1990, voting with "white ballots". On the other hand, the Macedonians in Pirin Macedonia became more and more engaged in the Organization and in the middle

\footnotetext{
${ }^{13}$ Ахил Тунтев, Република Македонија, прва декада (1990-1999), Скопје 2005, 424-425.

${ }^{14}$ One of the founders of OMO „Ilinden” was Sokrat Markilov (April 12, 1921, village of Butkovo, Aegean Macedonia - August 4, 1993, Banja Bansko, Strumica) who spent many years of his life in camps and prisons because of his activities for the rights of Macedonians in Pirin Macedonia. Стојко Стојков, ТАБУ. Време на страх и страдание. Преследването на Македонците в България по времето на комунизма (1944-1989), Сборник спомени и документи. Издава: Дружество на репресираните Македонци в България, Благоевград 2014, 150-151.

${ }^{15}$ Ахил Тунтев, Република Македонија..., 426.

${ }^{16}$ An appeal was lodged against this decision to the Supreme Court in Sofia, but on November 14, 1990. this court upheld the decision of the Blagoevgrad Court.
} 
of June 1990 they numbered about 40,000, with the largest numbers in Blagoevgrad, Simitli, Sandanski and Petrich. All this contributed to the holding of the First Congress of OMO "Ilinden" on August 2, 1990 in the village Oshtava, near Kresna, with the participation of 103 delegates and heads of local and city organizations, as well as representatives of "Ilinden-VMRO" from Sofia. Although informed in a timely manner, Bulgarian police violently disrupted the congress, confiscated work materials and detained the organizers. In response to the brutal Bulgarian policy, after the ban of OMO "Ilinden" in Blagoevgrad, in November and December 1990 an independent Society for the Protection of Human Rights was established.

At the same time, numerous organizations with the name of VMRO began to appear in Bulgaria ${ }^{17}$.

The activities of the Macedonians from Pirin Macedonia did not subside. On the contrary, on April 3, 1991 the Secretary of the Coordinating Board of OMO "Ilinden" Jordan Berbatov visited the President of the Assembly of the Republic of Macedonia Stojan Andov and asked for the Macedonian politics to work to acquaint the world public with the problems of the Organization and the position of the Macedonians in Bulgaria.

On April 19, 1991, Budimir Loncar, Federal Secretary for Foreign Affairs of the SFRY, accompanied by the Macedonian Minister Denko Maleski, paid an official visit to Bulgaria. A visit with representatives of the Macedonian national minority was also realized. After the meeting, Loncar said that "the current unsatisfactory position of Macedonians in Bulgaria has a prospect of improvement. On the contrary, Bulgarian Minister Viktor Volkov reiterated the official views that there is no Macedonian national minority in Pirin Macedonia" ${ }^{18}$. This statement came at a time when a second attempt was being made to mark the anniversary of the death of Jane Sandanski. And then the Bulgarian authorities used large police forces to prevent the Macedonians from holding the scheduled gathering at the Rozhen Monastery on Jane's grave. As a result, the Macedonians headed to Melnik to lay fresh flowers at the monument of Sandanski. On that occasion, the members of OMO "Ilinden" disclosed the Declaration and Appeal to the UN, EC and KEBS for the protection of the rights of Macedonians in Bulgaria. Having no effect, the constant engagement of the Macedonian minority in Bulgaria for the realization of the basic human rights in the country in which they live, the activists of OMO "Ilinden" in the second half of 1991, gained momentum internationally.

After the independence of Macedonia, Bulgaria recognized the independence of the Macedonian state, a statement was divulged, about which the first Macedonian President Kiro Gligorov wrote “... The Bulgarian government very wisely made its statement, saying that it recognizes the realities and avoids to say whose is this state of Macedonia, that it is a state of the Macedonian people, and not of a population living here" 19 . However, the "Great Bulgarian" unfulfilled dream was the reason for the Bulgarian recognition of the

\footnotetext{
${ }^{17}$ On December 14-15, 1990, the First Congress of VMRO SMD was held in Sofia. Namely, the former Unionof Macedonian Cultural and Educational Associations was renamed the ,socio-political organization” called VMRO SMD. Prof. Dimitar Gocev was elected President of the Organization.

Then, in late December 1990 and early 1991, another VMRO organization led by President Hristofor Tzavela has appeared in Sofia.

${ }^{18}$ Ахил Тунтев, Република Македонија..., 430.

${ }^{19}$ Киро Глигоров, Македонија еѐ с ито имаме, Скопје 2000, 408.
} 
state to be followed by the remark that the Macedonian people and language are not recognized, because they were "Bulgarian". Nevertheless, numerous agreements on bilateral co-operation between the Bulgarian and Macedonian states were signed, which was not easy at all. Namely, on April 13, 1994, talks were held on bilateral cooperation in education and science. The Bulgarian Minister of Education, Marko Todorov, refused to sign the Agreement on Cooperation in Science, Education and Culture because, according to him, the clause that the document is signed in Macedonian and Bulgarian was inadmissible. Two days later, he said in Sofia that the document could not be signed because "the Macedonian language does not exist" ${ }^{20}$. In fact, by this, the beginning of the so-called language dispute was publicly divulged. This dispute also caused obstruction during the visit of President Kiro Gligorov to the Republic of Bulgaria on April 25, 1994, when the previously agreed agreements were not signed. In the working part of the visit, Gligirov had the opportunity to speak in front of the Bulgarian Parliament, where he pledged “... to accept history as a lesson, to make the most of our own and other people's experience for the good of the free man, his own people, with awareness and responsibility that the world today is more deeply connected than ever"21.

In the meantime, the Macedonians from Bulgaria also worked in favor of recognizing the independence of the Macedonian state. Namely, in the beginning of April 1992, OMO "Ilinden" from Blagoevgrad appealed to the EC and other organizations for the immediate recognition of the Republic of Macedonia as an independent and sovereign state, in order to ensure democratic development in the Balkans. At a meeting of foreign ministers of the European Union (EU) member states in Luxembourg on April 6, 1992, it was assessed that the chances of recognizing Macedonia were higher than before, but the recognition didn't happen.

Not succumbing to injustice and pressure, the Macedonians in Pirin Macedonia continued their activities. Thus, after a long period of preparation and collection of documentation, on September 23, 1992, the organization "Traditional Macedonian organization VMRO, independent, Ilinden" was registered in Sofia under the leadership of Gjorgji Solunski. In addition to the activities for preservation and popularization of the Macedonian core, tradition and culture, the publication of a newspaper entitled "Independent Macedonia" and the magazine "Ilinden" was also planned"2.

A special challenge for work of the Macedonians in Bulgaria was the scheduled census for the period from 4 to 14 December 1992. Wanting to react in a timely manner to the injustices against the Macedonians by the Bulgarian government, on December 1, 1992, OMO "Ilinden" sent a protest to the CSCE stating that it was an opportunity for the people of Bulgaria to declare themselves as Bulgarians, Turks, Gypsies, Tatars, Jews, Armenians, Casabals, Circassians, Gagauzis and others, but did not mention Macedonians and the mother tongue - Macedonian. Regardless of everything, the Bulgarian government used pressure and intimidation during the census for Macedonians to declare themselves as Bulgarians and unprecedented propaganda was used to impose the thought that Bulgaria

\footnotetext{
${ }^{20}$ Ахил Тунтев, Република Македонија..., 133.

${ }^{21}$ Киро Глигоров, Македонија е сѐ ито имаме..., 413.

${ }^{22}$ However, in April 1993, the registration of this Organization by the Supreme Court of Bulgaria was suspended due to the participation of Solunski and its supporters in the celebration of the Rozhen manifestations.
} 
was a one-nation state on them. Quite shyly, on Bulgarian television, it was announced that $30 \%$ of the population in the Sandanski and Petrich areas had declared themselves Macedonians.

At the same time, Macedonian diplomacy was trying to find the most painless way for its international affirmation, due to which on November 25, 1992, the Consulate General of the Republic of Macedonia was opened in Sofia. It was the first step towards establishing full diplomatic relations between the two countries and opening an embassy of the Republic of Macedonia in Sofia, which took place on December 20, 1992. The exchange of notes on the establishment of diplomatic relations took place two days later ${ }^{23}$.

Unfortunately, all the efforts of the Macedonians in Bulgaria, independently or through the representatives of the Macedonian diplomacy in Bulgaria to get support or protection from the important international organizations for the protection of human rights, have remained completely ineffective. Due to the "deafness of the democrats from Europe", on March 10, 1994 the leader of OMO "Ilinden" Jordan Konstantinov held a press conference in Sofia and demanded the status of an autonomous region for Pirin Macedonia. "He condemned the Bulgarian authorities for genocide against Macedonians, who are being assimilated by not recognizing the Macedonian language and by physical and moral violence. He demanded the introduction of the mother tongue in schools and Macedonian nationality in the passports" 24 . The Bulgarian government reacted strongly to the statements and activities of the members and supporters of OMO "Ilinden", and the police, well informed by the long-eared and petty, intervened at every gathering of the Macedonians.

Since the independence of the R. of Macedonia to this day, the negative attitude of the Bulgarian policy towards the Macedonian sovereignty is constantly present. In other words, "the negative attitude of the Bulgarian political doctrine towards the Macedonian national identity, language and culture have been present for more than 130 years. This is an expression of the real knowledge that accepting the existence of a language different from Bulgarian, Macedonian, will automatically mean recognition of the existence of the Macedonian nation in Macedonia, separate from the Bulgarian state. The theory of that is especially synthetically explained by Ivan Mihajlov's VMRO between the two wars, consistently implemented after the Second World War ....

... How strongly the Bulgarian policy feels about that imaginary danger can best be seen in the example of Todor Zhivkov's policy.

For more than thirty years, during his tenure, representatives of the Bulgarian state in contacts with Macedonian and Yugoslav representatives will demand for Macedonia not to insist on the Macedonian minority in the Pirin part of Macedonia and its national rights..." ${ }^{25}$. Such a policy, according to Bulgarian politicians, should have continued until today in the R. of Macedonia.

Almost simultaneously with the Tantalean struggle of the Macedonian patriots in Bulgaria, after long diplomatic negotiations, on February 10, 1999, an agreement was reached in Sofia to overcome the language dispute between the R. Macedonia and the R. of Bulgaria, and the Declaration of Friendship and Cooperation between the Republic

\footnotetext{
${ }^{23}$ Спасе Мирчески, Алманах на Република Македонија..., 72.

${ }^{24}$ Ахил Тунтев, Република Македонија..., 435.

${ }^{25}$ Ivan Katardjiev, Macedonia and its neighbors, 31-40.
} 
of Macedonia and the Republic of Bulgaria was signed on February 22, 1999 by Macedonian Prime Minister, Ljupco Georgievski, and Bulgarian Prime Minister, Ivan Kostov. The declaration was signed in Bulgarian according to the Constitution of the Republic of Bulgaria and Macedonian according to the Constitution of the Republic of Macedonia. However, the Declaration provoked a torrent of reactions and interpretations about Art. $11^{26}$ of its text. However, the members of the organizations of the Macedonian minority in Pirin Macedonia reacted most strongly, considering that the indicated article meant resignation of the home country from its minority in neighboring Bulgaria. One of the biggest fighters for the basic rights of Macedonians in Bulgaria, Jordan Kostadinov-Ivanov" ${ }^{27}$, after the announcement of the draft declaration, said before it was signed: "We do not believe that any Macedonian government, and at least the current one, with the mentioned Declaration, or any other document, will be able to renounce the Macedonians in the neighboring countries and betray the Macedonian national interests..."28.

The activity of the Macedonians in Pirin Macedonia has continued in the following years.

But, also, the activities of the Bulgarian political elite with the denial of the Macedonian state in terms of the Macedonian language and history did not stop. On the contrary, they gained even more momentum after Bulgaria became a member of the European Union in 2007. From then until today, Bulgarian politicians do not miss the opportunity to "divulge the Bulgarian character" of the Macedonian language and Macedonian history. Despite the existence of a bilateral document on good neighborliness since 1999, for unknown reasons to the Macedonian people, on August 1, 2017, an agreement on good neighborliness, friendship and cooperation ${ }^{29}$ was signed, which provoked numerous negative reactions with the Macedonian public. Namely, the Agreement envisages the establishment of a joint Commission for educational and historical issues, which should "find" the so-called joint historical events and personalities, and thus ensure the "joint celebration of common history". In that way, the vampirization of the centuries-old spirit of San Stefano Bulgaria began in the conditions of the so-called European democracy in the 21 st century.

\footnotetext{
${ }^{26}$ Declaration of Friendship and Cooperation between the Republic of Macedonia and the Republic of Bulgaria:

"11. Both parties will not take, encourage and support one against the otheractions that have hostile character.

Neither party will allow its territory to be used against the other by organizations and groups aimed at carrying out subversive and separatist actions or actions aimed at endangering the peace and security of the other country ...

... Both parties will take effective measures to prevent ill-intentioned propaganda by institutions and agencies and will not allow the activities of private individuals aimed at inciting violence, hatred and other similar actions that would harm the relations between the Republic of Macedonia and the Republic. Bulgaria."

${ }^{27}$ Jordan Kostadinov Ivanov (born November 9, 1932 in Belica, Melnichko, Bulgaria - died August 23, 2019 in Sandanski, Bulgaria) - Macedonian national activist from the Pirin part of Macedonia, a fighter for the national rights of Macedonians under Bulgaria.

In 1990 he was one of the founders of OMO Ilinden and was elected president of the organization. He is the author of the book "The Fierceness of Bulgarian Nationalism and Its Servants Against the Macedonians".

${ }^{28}$ Јордан Костадинов - Иванов, Жестокотста на бугарскиот национализам и неговите слуги против Македонците, “Нова Македонија” 19 февруари 1999 год.

${ }^{29} \mathrm{https}$ ://akademik.mk/ potpisan-dogovorot-za-dobrososedstvo-prijatelstvo-i-sorabotka-megju-makedonija-ibugarija/
} 
As for the relations of Macedonia with its northern neighbor, apart from the problems with the Macedonian Orthodox Church, in the period from independence until today, only occasionally political disagreements appear.

The Macedonian population in Serbia is an officially recognized minority. According to the 2002 census, 25,847 Macedonians live in Serbia, 14,062 of them in Central Serbia and 11,785 in Vojvodina. The highest concentrations of Macedonians are in Plandishte, Jabuka, Glogonj and Kacharevo where they represent $10-32 \%$ of the total population. If we consider the fact that the Goranis are also part of the Macedonian people, then according to the 2002 census, 4,581 Gorani lived in Serbia (excluding Kosovo and Metohija). It is estimated that there are over 60,000 Gorani. The Democratic Party of Macedonians was formed in Serbia, whose member Mile Spirovski, in 2012, became the first Macedonian member of the Serbian Parliament. He is also a member of the Association of Macedonian Fine Arts Artists in Serbia. On January 19, 2016, a founding assembly was held in Belgrade to form the new Party of Macedonians in Serbia. Goran Ilijevski was elected president of the party, while Ana Sinicki, Daniela Cvetanovikj and Slave Gruevski were appointed vice presidents. Biljana Miloshevski was elected secretary of the party ${ }^{30}$. The activities of the Macedonians in the Republic of Serbia are numerous and aimed at preserving the Macedonian tradition, history and culture.

The Macedonian state, since its independence, has had the biggest obstructions with its southern neighbor, Greece. For many years, from 1913 onwards, a part of the Macedonian territory inhabited by the Macedonian population has been part of the Greek territory. The Greek state, wanting to assimilate and denationalize that population and portray Greece as an ethnically pure state inhabited only by Greeks, took draconian measures against the Macedonians. At a time when the break-up of the Yugoslav federation and the independence of Macedonia as a state was in sight, a Ministry of Northern Greece and Thrace was set up as a "preventive" measure in Greece, because Macedonia was not allowed to be mentioned. The first man of the Ministry, Papatemelis, conscientiously pushed the agenda of punishing anyone who speaks Macedonian or sings a Macedonian song for decades. At that time, the first red lights in Greek politics were lit, and the beginning marked the renaming of the mentioned Ministry of Northern Greece and Thrace to the Ministry of Macedonia and Thrace, and later Thrace was removed from the name. Then, for the first time in modern Greek history, the desire of the Hellenes (Ellines) or Greeks to become Macedonians arose.

The independence of the Macedonian state was received with great disapproval in the Greek society, and its self-will was also supported by the international community. As a result, Macedonia had to change its new flag with the 16-pointed sun from Kutlesh, the Macedonian state had to accept humiliation by renaming it the former Yugoslav Republic of Macedonia in order to join the United Nations, and had to change the Constitution and specify that it will not take care of the Macedonians in the neighborhood. In fact, Greece was disturbed by the historical truth that Macedonians on its territory are a native Macedonian population. As a result, during the "Greekization" of Aegean Macedonia, many Macedonians, living now around the world, were expelled, and according to all international documents, they were entitled to their property in "democratic" Greece. However, the

\footnotetext{
${ }^{30} \mathrm{https}$ ://meta.mk/nova-partija-na-makedontsite-vo-srbija/
} 
Greek, so-called democrats did not stop there, but in every way and on every occasion they used to stop the Macedonian state in its efforts to become a member of international organizations ${ }^{31}$. After using all other trump cards, Greece used the name of the state of the Republic of Macedonia for its extremely undemocratic methods of regression of the European path and humiliation of the Macedonian state and the Macedonian people. In this regard, the Greek state stopped Macedonia's entry into the NATO alliance in 2008 by putting a veto on the proposal for Macedonia's accession to NATO.

In order to exercise its internationally guaranteed rights, and based on the Interim Accord between Macedonia and Greece, the Macedonian party filed a lawsuit against Greece before the International Court of Justice in the Hague. On November 22, 2011, the International Court ruled that Greece violated the Interim Accord, the judges at the tribunal ruled that Macedonia's lawsuit against its southern neighbor is justified. But that changed nothing in the attitude of Greek politicians towards either the Macedonian state or the Macedonian minority on its territory. On the contrary.

Under the threats and blackmail of the Greek "democracy", the Macedonian party gave in and on June 17, 2018 signed the "Final Agreement on Resolving the Differences Described in Resolutions 817 (1993) and 845 (1993) of the United Nations Security Council to cease the validity of the 1995 Interim Accord and for establishing a strategic partnership between the parties. "It is an agreement known to the public as the "Prespa Agreement", under which Greece exercised its "democratic" rights to rename the Macedonian state. Thus, Macedonia again received a pejorative name and became the only country in the world with a geographical designation in the official name. In a referendum held on September 30, 2018 for the (non) acceptance of the so-called "Prespa Agreement" the Macedonian people rejected the agreement. However, this was not an obstacle for the Parliament and the Government of Macedonia to declare the referendum, declared by the Macedonian people, "consultative" without any significance for their opinion.

As for the Macedonians in Greece, who considered themselves living in a democratic state and should have basic human rights according to world documents, in 1994 they formed the Rainbow Party, a political party of Macedonians in Aegean Macedonia. The Rainbow does not consider itself to be a separatist party, an allegation made by the Greek government $^{32}$. The party's headquarters are in the town of Florina. Rainbow is a member of the European Free Alliance. The party and its activists have been convicted, and their party offices have been set on fire and robbed. They are under constant attack and pressure from the Greek media.

The European Court of Human Rights has ruled that the Greek government is guilty of violating the European Convention on Human Rights over a political party. The court ordered the Greek government to pay the party compensation in the amount of EUR 35,000, which the Rainbow used to reissue the Elementary Education Textbook (Alphabet), in Macedonian, made by the Greek government since 1925, under pressure from the League of Nations, which was successfully presented in Thessaloniki and Athens at the end of

${ }^{31}$ For the role of Greece in stopping the Macedonian state in its international establishment, see more in Киро Глигоров, Македонија е сѐ ито имаме..., 75-110.

${ }^{32}$ https://mk.wikipedia.org/wiki/\%D0\%92\%D0\%B8\%D0\%BD\%D0\%BE\%D0\%B6\%D0\%B8\%D1\%82\% D0\%BE_(\%D0\%BF\%D0\%BE\%D0\%BB $\%$ D0 $\%$ B $8 \%$ D $1 \% 82 \%$ D0 $\%$ B $8 \%$ D $1 \% 87 \%$ D0 $\%$ BA $\%$ D0 $\%$ B0_ $\%$ D0 $\%$ BF\%D0\%B0\%D1\%80\%D1\%82\%D0\%B8\%D1\%98\%D0\%B0) 
2006, with the great support of the Macedonians from Aegean Macedonia and a large number of Greek intellectuals.

The Macedonian state continues to exist in such a "good neighborly" environment and prove itself before international institutions and also fight for a dignified entry into the European family.

\section{Bibliography}

Глигоров К., Македонија е сѐ ито имаме, Скопје 2000.

Katardjiev I., Macedonia and its Neighbors, Skopje 2001.

Мирчески С., Алманах на Република Македонија (хронологија 1990-1997), Скопје 1998.

Тодороска К., Македониите во Албанија (1912-1991), Скопје 2016.

Тунтев А., Република Македонија, прва декада (1990-1999), Скопје 2005.

https://akademik.mk/ potpisan-dogovorot-za-dobrososedstvo-prijatelstvo-i-sorabotka-megju-makedonija-i-bugarija/

https://meta.mk/nova-partija-na-makedontsite-vo-srbija/

Katerina Todoroska, prof. dr, historyk, politolog, pracownik Instytutu Historii Narodowej w Skopiu (Północna Macedonia). W swych pracach zajmuje się rolą UE w procesach demokratyzacyjnych Bałkanów Zachodnich, głównie w Macedonii Północnej, a także mniejszością albańską w tym państwie. Jest autorką wielu prac, m.in.: Конгресите за унифицирање на албанското писмо, Skopje 2018; Положбата на македонското население во Албанија (1912-1916), Skopje 2019. W 2020 r. otrzymała prestiżową nagrodę - Ilinden za zasługi w dziedzinie naukowej. 